\title{
(2) OPEN ACCESS \\ Targeting lung cancer screening to individuals at greatest risk: the role of genetic factors
}

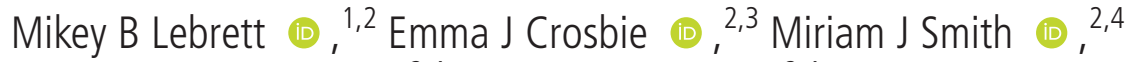 \\ Emma R Woodward (ㅇ, , 2,4 D Gareth Evans (1) , 2,4 Philip A J Crosbie (1) 1,2,5
}

${ }^{1}$ Division of Infection, Immunity and Respiratory Medicine, The University of Manchester Faculty of Biology Medicine and Health, Manchester, UK

${ }^{2}$ Prevention and Early Detection Theme, NIHR Manchester Biomedical Research Centre, Manchester, UK

${ }^{3}$ Division of Cancer Sciences, The University of Manchester Faculty of Biology Medicine and Health, Manchester, UK

${ }^{4}$ Manchester Centre for Genomic Medicine, St Mary's Hospital, Division of Evolution and Genomic Sciences, School of Biological Sciences, University of Manchester, Manchester, UK ${ }^{5}$ Manchester Thoracic Oncology Centre, Wythenshawe Hospital, Manchester University NHS Foundation Trust, Manchester, UK

\section{Correspondence to} Dr Philip A J Crosbie, Manchester Thoracic Oncology Centre, North West Lung Centre, Manchester University NHS Foundation Trust, Wythenshawe M23 9LT, UK;

philip.crosbie@manchester. ac.uk

Received 12 August 2020 Revised 6 December 2020 Accepted 8 December 2020 Published Online First 29 January 2021

Check for updates

(c) Author(s) (or their employer(s)) 2021. Re-use permitted under CC BY. Published by BMJ.

To cite: Lebrett $\mathrm{MB}$ Crosbie EJ, Smith MJ, et al. $J$ Med Genet

2021:58:217-226

\section{ABSTRACT}

Lung cancer $(\mathrm{LC})$ is the most common global cancer. An individual's risk of developing LC is mediated by an array of factors, including family history of the disease. Considerable research into genetic risk factors for LC has taken place in recent years, with both low-penetrance and high-penetrance variants implicated in increasing or decreasing a person's risk of the disease. LC is the leading cause of cancer death worldwide; poor survival is driven by late onset of non-specific symptoms, resulting in late-stage diagnoses. Evidence for the efficacy of screening in detecting cancer earlier, thereby reducing lung-cancer specific mortality, is now well established. To ensure the cost-effectiveness of a screening programme and to limit the potential harms to participants, a risk threshold for screening eligibility is required. Risk prediction models (RPMs), which provide an individual's personal risk of LC over a particular period based on a large number of risk factors, may improve the selection of high-risk individuals for LC screening when compared with generalised eligibility criteria that only consider smoking history and age. No currently used RPM integrates genetic risk factors into its calculation of risk. This review provides an overview of the evidence for $L C$ screening, screening related harms and the use of RPMs in screening cohort selection. It gives a synopsis of the known genetic risk factors for lung cancer and discusses the evidence for including them in RPMs, focusing in particular on the use of polygenic risk scores to increase the accuracy of targeted lung cancer screening.

\section{INTRODUCTION}

Lung cancer is the leading cause of cancer death worldwide. It is the most common cancer in men and the third most common cancer in women. ${ }^{1}$ There were an estimated 2.1 million new cases and 1.8 million deaths in 2018, representing almost $12 \%$ of all cancer diagnoses and $18 \%$ of cancer deaths globally. In the UK, 47000 new cases are diagnosed each year, ${ }^{2}$ and it is responsible for one in five cancer deaths. ${ }^{3}$ Lung cancer is classified into two main types, non-small cell lung cancer (NSCLC) and small cell lung cancer (SCLC). NSCLC is responsible for approximately $85 \%$ of cases and is composed of a number of histological subtypes, most commonly adenocarcinoma, squamous cell carcinoma and large cell carcinoma. ${ }^{4}$ While less common, SCLC is more aggressive than NSCLC, with faster doubling times and a higher tendency to metastasise at an earlier stage. ${ }^{5}$

Smoking and age are the two most important risk factors for lung cancer. In the UK, smoking is estimated to cause up to $86 \%$ of cases. ${ }^{67}$ This risk rises with both smoking duration and number of cigarettes smoked each day. ${ }^{8}$ Just under half of cases occur in people aged over 75 years. The highest rate of lung cancer occurs between the ages of 80 and 84 years in women and 85-89 years in men. ${ }^{9}$ Several other risk factors increase a person's chance of developing lung cancer, particularly radon exposure, ${ }^{10}$ workplace exposure to asbestos and other harmful agents (responsible for $\approx 13 \%$ of UK case $^{6}$ ), socioeconomic deprivation, ${ }^{11}$ previous diagnosis of a malignant tumour, ${ }^{12}$ previous diagnosis of respiratory conditions such as chronic obstructive pulmonary disease (COPD) $)^{13-15}$ (the evidence for pneumonia and tuberculosis is less well established ${ }^{14}{ }^{16}$ ), family history, ${ }^{18}$ as well as particular rare hereditary disorders such as $\mathrm{Li}$ Fraumeni syndrome ${ }^{19}$ and the recently described non-syndromic association with germline EGFR mutation. ${ }^{20}$ The impact of female sex on lung cancer risk is debated. ${ }^{8} 21-23$

Lung cancer survival is poor. Overall, only $40 \%$ of patients in England and Wales survive for 1 year following diagnosis, with this proportion dropping to approximately $16 \%$ survival over 5 years and $10 \%$ over 10 years. $^{24}$ While 1 -year survival in England and Wales has increased significantly since the 1970s, long-term survival rates have only seen a modest improvement; for example, the 5-year agestandardised survival rate increased by just $4 \%$ for men and 7\% for women between 1971 and 2011. ${ }^{25}$ This stands in stark contrast to the doubling of overall cancer survival in the UK over the past 40 years. $^{26}$

The late clinical presentation of lung cancer is a major reason for its low survival rates and poor prognosis. In the UK, around half of patients have distant metastases and therefore incurable stage IV disease at the time of diagnosis compared with just a quarter with stage I or stage II disease. ${ }^{27}$ The 1 -year survival rate of stage IV disease is $17 \%$, compared with $83 \%$ for those diagnosed at stage I. ${ }^{28}$ Even within stage I, survival is predicted by tumour diameter. Five-year survival decreases by $5 \%$ for each $1 \mathrm{~cm}$ that tumour diameter increases; this emphasises the importance of early detection, even at the earliest stage of lung cancer development. ${ }^{29}$

The primary reason lung cancer is diagnosed at a late stage is that early stage disease is often asymptomatic, and when symptoms do develop, they are usually mild and non-specific resulting in diagnostic delay. For example, fatigue, shortness of breath, cough, chest pain and persistent chest infections are all common symptoms of lung cancer but are also symptoms of other smoking-related conditions, 
such as COPD, which commonly coexist in patients with lung cancer. $^{30}$

The key to improving patient outcomes is early detection. Low dose CT (LDCT) screening for those at high risk detects early stage lung cancer and reduces lung cancer specific mortality. Risk prediction models (RPMs) are used to select a high-risk cohort for screening. Currently, RPMs do not include a direct measure of genetic risk as a variable, as the evidence for the significance of genetic risk factors in lung cancer is still emerging. Here, we summarise the evidence for screening and various methods of screening cohort selection, focusing in particular on the contribution of genetics to lung cancer risk, and thereby in the potential of using genetic factors in selecting individuals for screening.

\section{EVIDENCE FOR THE EFFECTIVENESS OF LUNG CANCER SCREENING}

Several approaches to screening have been trialled over the years. A meta-analysis published by Cochrane in 2004 concluded that there is no benefit derived from chest X-ray (CXR) or sputum cytology for lung cancer screening, modalities that had predominated screening trials since the $1960 \mathrm{~s} .{ }^{31}$ This was confirmed in 2011 by the large Prostate, Lung, Colorectal, and Ovarian (PLCO) Cancer Screening Trial that randomised 154901 participants into CXR and standard care arms; there was no reduction in lung cancer mortality in the CXR cohort. ${ }^{32}$ LDCT emerged as a superior alternative to CXR for lung cancer screening in the 1990s. In a Japanese study of 1369 high-risk individuals, LDCT successfully identified 15 cases of lung cancer, 11 of which were missed by CXR. Most of the screen-detected cancers were stage I. ${ }^{33}$ The International Early Lung Cancer Action Program was the first international multicentre LDCT programme, running from 1993 to 2005. The programme screened 31567 high-risk individuals, 27456 of which had a repeat screening 1 year after baseline. LDCT screening identified 484 lung cancers, $85 \%$ of which were stage I. ${ }^{34}$

Evidence of a disease-specific mortality reduction from lung cancer screening was first demonstrated by the USAbased National Lung Screening Trial (NLST). This large study randomised 53454 current or former smokers ( $\geq 30$ packyears, smoked within 15 years), age 55-74 years at recruitment, to either annual LDCT or CXR over three screening rounds. LDCT screening detected lung cancer at an earlier stage (50\% stage I) compared with the CXR arm (31\% stage I). This resulted in a $20 \%$ reduction in lung cancer specific mortality and $6.7 \%$ reduction in all-cause mortality. ${ }^{35}$ The Dutch-Belgian Randomised Lung Cancer Screening Trial (NELSON) randomised 13195 men and 2594 women age 50-75 years to either four rounds of LDCT screening over 5.5 years or no screening. All participants were current or former smokers who had smoked within 10 years and had a tobacco exposure of either $\geq 15$ cigarettes per day for 25 years or $\geq 10$ cigarettes per day for 30 years. NELSON confirmed NLST findings in a European population, reporting a $26 \%$ reduction in lung cancer deaths among men and a $33 \%$ reduction in lung cancer deaths among women with LDCT screening after 10 years of follow-up. ${ }^{36}$ The German Lung Cancer Screening Intervention trial showed an even larger discrepancy between the screening benefits derived by male and female screening cohorts, with women experiencing a statistically significant reduction in lung cancer mortality that was not replicated among men. ${ }^{37}$ The recently published Multicentric Italian Lung Detection (MILD) trial (age 50-75 years, current or former smokers within 10 years, $\geq 20$ pack-years) reported a $39 \%$ reduction in lung cancer mortality over 10 years due to LDCT screening. ${ }^{38}$

\section{SCREENING-RELATED HARMS}

While there is significant evidence for the benefit of lung cancer screening, potential harms of screening must be considered. Overdiagnosis occurs when tumours are detected through screening that have no clinical consequence. This may result in the patient undergoing invasive treatment, exposing them to unnecessary harms to remove a tumour that would never have shortened their life or impaired its quality. ${ }^{39}$ Overdiagnosis has affected lung cancer screening trials in the past; 16 years of follow-up to a historic screening trial of CXR and sputum cytology found a likely overdiagnosis rate of $51 \% .^{40}$ More recent LDCT screening trials have lower, although still significant, overdiagnosis rates. The NELSON trial reported an upper overdiagnosis rate of between $8.9 \%$ and $19.7 \%$ depending on the length of follow-up considered. ${ }^{36}$ One study initially estimated the overdiagnosis rate in NLST to be up to $18.5 \%{ }^{41}$; however, with extended follow-up, this estimate is now reported to be approximately $3 \%{ }^{42}$

False-positive results (in which scan findings mandate further investigation with no eventual cancer diagnosis) can result in a notable, although transient, spike in anxiety as well as invasive and unnecessary investigations. ${ }^{43}{ }^{44}$ Some studies have shown long-term negative psychosocial impacts of a false-positive screening result. ${ }^{45}$ Adverse events related to invasive diagnostic procedures such as CT-guided biopsies are a significant potential harm of screening, particularly in individuals who are eventually found not to have lung cancer; one meta-analysis reported a $38.8 \%$ overall complication rate and $5.7 \%$ major complication rate for core biopsies of the lung. ${ }^{46}$ Radiation exposure from LDCT scans is also a potential harm (although the actual increased risk is minimal ${ }^{47}$ ).

While mitigating screening-related harms is a complex and multifaceted exercise, improved precision of lung cancer risk prediction increases the overall risk profile of the screening cohort, thereby improving the risk-to-benefit ratio. For example, risk stratification in breast cancer screening has been shown to decrease the overdiagnosis rate by $27 \%$. $^{48}$

\section{USE OF RISK PREDICTION MODELS TO SELECT SCREENING PARTICIPANTS FOR LDCT}

NLST, NELSON and MILD selected screening participants solely based on age and smoking history. These generalised eligibility criteria serve as a rudimentary risk threshold for screening but do not predict an individual's personal risk of lung cancer. This resulted in a screening cohort with a heterogeneous mix of risk profiles. Retrospective analysis of the NLST cohort stratified by lung cancer risk demonstrated marked variation in screening benefits and harms. Only 1\% of lung cancer deaths prevented by LDCT screening were found in the lowest risk quintile despite similar exposure to screening harms. ${ }^{49}$ The number needed to screen to prevent one death was 161 in the highest risk group and 5276 in the lowest. It has been proposed that replacing generic eligibility criteria with a personalised lung cancer RPM could be a more effective way of selecting high-risk individuals for screening by LDCT. RPMs use several variables to estimate a specific individual's risk of developing a disease over a period of time. Selection in this manner results in a screening cohort with a higher risk profile, thereby improving cost-effectiveness and efficacy of the programme, as well as reducing screening-related harms. ${ }^{5051}$ 
More than 20 RPMs have been created for lung cancer. ${ }^{52}$ The Liverpool Lung Project (LLP) model is a validated RPM which, in addition to age and tobacco smoke exposure, includes asbestos exposure, sex, previous pneumonia diagnosis and previous cancer diagnoses as variables. ${ }^{23}$ This RPM was used prospectively in the UK Lung Cancer Screening Trial, in which 4055 participants were selected (based on an individualised 5 -year lung cancer risk score of $\geq 5 \%$ ) and randomised into LDCT screening or standard care (no screening) groups. In the screening group, 42 participants were diagnosed with lung cancer (2.1\%), 85.7\% of which were stage I or stage II at the time of diagnosis. ${ }^{53}$ As well as showing the efficacy of RPM use for screening selection, the study also demonstrated that lung cancer screening, based on individual risk, could be cost-effective within a UK-based healthcare setting.

$\mathrm{PLCO}_{\mathrm{M} 2012}$ is a logistic regression model developed using the disease incidence data of more than 80000 smokers taking part in the PLCO cancer screening trial. ${ }^{8}$ In addition to tobacco smoke exposure and age, $\mathrm{PLCO}_{\mathrm{M} 2012}$ considers deprivation level (using educational attainment as a surrogate marker), COPD diagnosis, ethnicity, family history of lung cancer, personal history of cancer and BMI as risk factors. It was initially validated using the NLST cohort and has since been validated in several other trials. ${ }^{54}$ Studies have shown that $\mathrm{PLCO}_{\mathrm{M} 2012}$ increases the proportion of people selected for screening who have lung cancer when compared with generalised eligibility criteria. ${ }^{85}$ The model was employed successfully to determine screening eligibility in the Manchester Lung Health Check Pilot. A total of 1429 high-risk individuals were screened in the context of a commissioned service within the National Health Service (NHS). The risk threshold for LDCT screening was PLCO $_{\mathrm{M} 2012} \geq 1.51 \%{ }^{56}$; at this threshold, $\mathrm{PLCO}_{\mathrm{M} 2012}$ has been shown to have improved sensitivity, specificity and positive predictive value for lung cancer detection compared with NLST generalised eligibility criteria. ${ }^{55}$ Across the trial, $4.4 \%$ of the cohort was diagnosed with lung cancer, more than double the rate found by NLST. ${ }^{57}$ Retrospective analysis found that within the group of patients with cancer diagnosed, $\mathrm{PLCO}_{\mathrm{M} 2012}$ and $\operatorname{LLP}_{\mathrm{v} 2}$ at a $\geq 2.5 \%$ risk threshold would have outperformed NLST generalised eligibility criteria that would have missed $18 \%$ of cancers. ${ }^{58}$ Based on the success of this pilot, NHS England have commissioned a further 10 screening pilots across the country. ${ }^{59}$

Generalised eligibility criteria select screening participants based on the two main risk factors of lung cancer, tobacco smoke exposure and age. Relying solely on these variables presents a number of limitations. USPSTF generalised eligibility criteria recommend lung cancer screening be offered to those aged 55-80 years who are current smokers or who have quit in the past 15 years. Despite the immediate and considerable benefits of smoking cessation, ${ }^{60}$ a recent meta-analysis confirmed that ever-smokers maintain an increased level of lung cancer risk well after 15 years since quitting ${ }^{61}$; other studies have demonstrated increased lung cancer incidence even 25 years after quitting. ${ }^{62}$ Consequently, these selection criteria may exclude previous smokers who remain at a heightened risk of lung cancer. Additionally, while age is an accurate predictor of lung cancer, older populations display considerable heterogeneity in their health trajectories. ${ }^{63}$ Consequently, biological age is a better indicator of health outcomes than chronological age. However, biomarkers and clinical measures of biological age are not well developed. ${ }^{64}$ The supplementary risk factors considered in all RPMs assist in targeting screening to the most at-risk individuals, bypassing the limitations of establishing screening eligibility by smoking history and age alone. Germline genetic biomarkers may be particularly valuable in this regard, as unlike other risk factors, they stay constant throughout a person's life and are not impacted by smoking history.

\section{GENETIC FACTORS AND LUNG CANCER RISK Epidemiology}

Having a first-degree relative who has been diagnosed with lung cancer increases a person's risk of also developing the disease. ${ }^{65}$ An individual with multiple family members diagnosed with lung cancer is at even greater risk; early onset lung cancer in affected family members also increases personal risk. ${ }^{18}$ While shared environmental and lifestyle factors within families are certainly responsible for part of the increased familial lung cancer risk, research over the past few years has established that there is an important hereditary genetic contribution as well. A pooled analysis of over 24000 lung cancer cases found that after controlling for smoking and other confounding environmental factors, there was a 1.51-fold increase in risk of lung cancer in those who had a first-degree relative with the disease. Individuals with a sibling diagnosed with lung cancer were found to be at the highest increased risk, even after controlling for tobacco exposure. ${ }^{66}$ It should be noted that this pooled analysis only includes casecontrol studies that may be affected by sampling bias. Whether the magnitude of the effect reported would be reproduced at a population level in a prospective cohort is unclear. Despite this limitation, the implication of a significant familial element to increased lung cancer risk, with a potential genetic contribution, remains strongly supported by this and other studies.

A large Icelandic study found that spouses of patients with lung cancer have a 1.75 -fold increased risk of lung cancer, indicating that shared environment is an important factor in the development of lung cancer. The same study demonstrated that first-degree relatives had a greater risk, up to a 3.5 -fold increase. Although this observation may be due to the interplay between environmental and genetic factors, the exact nature of this interaction and the mechanism of genetic susceptibility are not elucidated ${ }^{67} \mathrm{~A}$ multicentre study found that the risk of lung cancer increases with family history of the disease even among non-smoking women, providing further evidence that there is an important genetic contribution. ${ }^{68}$ Similarly, another study showed that non-smoking relatives of never-smoker lung cancer patients have a higher risk of contracting the disease when compared with controls, even though tobacco smoke did not contribute. ${ }^{69}$ Increased genetic risk of lung cancer may be particularly vital when it comes to early onset lung cancer, ${ }^{70}$ as well as multiple primary lung cancers. ${ }^{71}$ A study of 230 never-smokers with lung cancer found that $18 \%$ had family history of the disease, and a large proportion had specific genetic pathogenic variants that increase an individual's susceptibility to developing lung cancer. ${ }^{72}$ A large prospective twin-based study estimated that the overall heritability of lung cancer is $18 \% .{ }^{73}$ Heritability refers to the limit of genetic risk stratification on a population level and individuals may have a much higher level of genetically conferred lung cancer risk. ${ }^{74}$ These studies demonstrate the importance of genetic variables in defining lung cancer risk.

\section{Monogenic variants}

Although there is strong evidence for a familial component of lung cancer, there is limited evidence that pathogenic variants in single genes confer high risk of lung cancer. A notable exception is the rare cancer predisposition syndrome, Li Fraumeni syndrome, arising from germline TP53 pathogenic variants. ${ }^{75}$ While typically associated with sarcoma, breast and brain 
tumours, leukaemia, lymphoma and adrenocortical carcinoma, instances of lung cancer in Li Fraumeni syndrome have also been described. ${ }^{7677}$

Considerable research has taken place in the past decades to search for other significant single-gene variants associated with lung cancer risk. Several rare inherited EGFR variants are associated with lung cancer risk ${ }^{78}$; while the mechanism through which these variants increase disease risk is not confirmed, one possibility might be that the mutation causes genetic instability that predisposes cells to somatic mutations and tumourigenesis ${ }^{20}$; for example, the T790M variant in EGFR is both a germline variant associated with lung cancer and an important somatic variant with implications for therapy. ${ }^{79} 80$ The rarity and unclear penetrance of germline EGFR mutations makes discovery and subsequent management challenging.

Segregation analyses of families with high lung cancer incidence has provided some evidence for the existence of a rare major autosomal inherited allele that could contribute to a significant increase in lung cancer risk in its carriers. ${ }^{81-83}$ This hypothesis was further supported by a linkage analysis study of 52 high-risk families indicating a locus containing an inherited high-penetrance allele significantly associated with lung cancer risk to chr6q. ${ }^{84}$ A further study published in 2010 supported the implication of this chromosomal region in increasing lung cancer risk, even in never smokers ${ }^{85}$; fine mapping implicated the gene RGS17 within this region as a likely candidate for familial lung cancer susceptibility. ${ }^{86}$ While RGS17 overexpression has been shown to aid tumour cell proliferation, it has not been convincingly proven as a lung cancer susceptibility gene. ${ }^{87}$ A study published in 2015 demonstrated that a high-penetrance missense mutation in the YAP1 oncogene significantly increases the risk of lung cancer. ${ }^{88}$ Another reported association was with the c. $823 \mathrm{C}>\mathrm{T}$ (p.Arg275Trp) missense variant in PARK2. ${ }^{89}$ However, given its low allele frequency in gnomAD $(<0.002)$ and its lack of subsequent validation, it appears unlikely to be a high-risk allele. ${ }^{90}$ Overall, while useful for explaining the occurrence of some familial cancer, the rarity of high-penetrance variants within the population limits their usefulness in the context of routine, prescreening risk prediction for selecting a cohort from the general population. Consequently, the search for high frequency, low-penetrance alleles associated with lung cancer has become a more promising endeavour in recent years.

\section{Polygenic variants}

Most of the accumulated evidence is of a polygenic inheritance pattern. There is now a large array of low-penetrance genetic variants identified, which either increase or decrease lung cancer risk by small amounts. These variants are usually discovered in genome wide association studies (GWAS). In a GWAS, hundreds of thousands or millions of SNPs are genotyped with the aim of finding variants that are present at a significantly higher frequency in the case group when compared with the control group. An OR can then be calculated, indicating the likelihood of a particular outcome (lung cancer) based on the presence of an exposure (a particular genetic variant). Genome wide significance for an allele is usually established with a $\mathrm{p}$ value of less than $5 \times 10^{-7}$.

Since 2008, there have been over 45 genetic loci associated with lung cancer risk discovered by many thousands of GWAS, although the strength of evidence varies in each case. ${ }^{91}$ Metaanalyses seek to synthesise the large volume of (often conflicting) evidence generated by GWAS and case-control studies to generate a list of SNPs with robust association with lung cancer risk. For example, a large meta-analysis published in 2017 examined 246 genetic variants from 138 loci sourced from more than 1000 publications published until 2015. The mean number of cases in the studies analysed was 414 (range 13-4257), with the mean number of controls being 565 (range 12-55 823). The meta-analysis concluded that 22 variants in 21 genes showed significant association with lung cancer with strong cumulative epidemiological evidence (as graded by the Venice Criteria ${ }^{92}$ ). It also found a significant level of heterogeneity between the SNPs associated with various subgroups, including ethnicity, lung cancer histology and smoking status. ${ }^{93}$ A large number of metaanalyses such as this have been published in recent years. ${ }^{94}$

A review published in 2017 aimed to summarise and assess the evidence relating to lung cancer associated SNPs from more than 200 separate meta-analyses and GWAS, all published up to 2016 with at least 1000 cases. $^{94}$ The majority of studies contained two or more ethnicities, although nine were limited to a specific ethnicity (six Asian and three Caucasian). The mean total sample size was 23 000; the median was 10551 (the range was 1095 150256). In total, the study yielded 137 SNPs associated with lung cancer risk, 80 of which were statistically significant. SNPs derived from meta-analyses were graded for strength of evidence using Venice Criteria and false positive report probability ${ }^{95}$; of the variants derived from the meta-analyses, 15 SNPs were graded as 'strong' for evidence of association and 19 SNPs were graded as 'moderate'. This review did not weigh and synthesise the evidence for each SNP as a formal meta-analysis would have; when there was conflicting evidence from different studies, the evidence from the largest study was treated as authoritative. Nevertheless, this study serves as an important summary of the SNPs likely to exhibit robust association with lung cancer.

Since the publication of these studies, a further large casecontrol study was published in 2017. A total of 14803 lung cancer cases and 12262 controls were genotyped and aggregated with existing data resulting in an analysis of 29266 cases and 56450 controls. $^{96}$ This study reported the discovery of 10 novel SNPs significantly associated with lung cancer, as well as the confirmation of $8 \mathrm{SNPs}$ previously reported. The study claims to identify the SNPs responsible for $12.3 \%$ of the additional familial relative risk of lung cancer.

A considerable number of SNPs associated with increased lung cancer risk in European populations are localised to three particular gene clusters.

\section{CHRNA}

The CHRNA gene cluster is located in the $15 \mathrm{q} 25$ chromosomal region; variants within this region are strongly associated with lung cancer risk. For example, AA risk genotype at rs16969968 in CHRNA5 is associated with both an increased risk and earlier diagnosis of lung cancer. ${ }^{97}$ Expression of the gene has been found to contribute to cancer cell signalling, proliferation, inhibition of apoptosis and angiogenesis. ${ }^{98}$ Additionally, studies have identified CHRNA5 as having a role in nicotine addiction and dependency. ${ }^{99}$ Several studies have demonstrated that increased lung cancer risk is an independent association related to SNPs in this gene. ${ }^{100-102}$ SNP rs1051730 in the CHRNA gene is a variant with significantly robust association with lung cancer risk in European populations. $^{94}$

\section{CLPTM1L}

The CLPTM1L gene is located in the $5 \mathrm{p} 15$ chromosomal region; two variants (rs401681 and rs402710) are particularly strongly associated with increased lung cancer risk. ${ }^{103}$ It has 
been proposed that the gene segment containing these polymorphisms may regulate telomerase reverse transcriptase expression, allowing cells to resist apoptosis and become malignant. ${ }^{104}$

\section{BAT3}

The BAT3 gene is located in the $6 \mathrm{p} 21$ chromosomal region. The protein product of this gene cluster has been shown to be crucial in p53 acetylation during the repair or apoptosis of damaged, potentially malignant, cells. BAT3 may also be released in response to stress signals, engaging natural killer cells to target tumour cells. ${ }^{105}$

\section{USING GENETIC RISK FACTORS TO SELECT INDIVIDUALS FOR SCREENING}

The potential for inclusion of genetic risk factors in RPMs to improve risk prediction has been demonstrated in several disease areas, most notably breast cancer. High-penetrance genetic variants have been include in the Tyrer-Cuzick, BOADICEA and BRCAPRO models for breast cancer risk prediction, which use $B R C A 1 / 2$ mutation carrier status as a risk factor. ${ }^{106}$ In recent years, research has demonstrated the efficacy of employing a polygenic risk score (PRS) of low-penetrance SNPs in disease risk prediction. A PRS combines a selection of SNPs known to influence an individual's risk of developing a disease; while each SNP may only have a minimal impact individually, when combined, they can alter risk significantly. A recent study demonstrated the utility of a PRS of 313 SNPs in breast cancer risk prediction. ${ }^{107}$ There is also evidence that PRS usage could reduce overdiagnosis in prostate cancer screening programmes, ${ }^{108}$ as well as facilitate the stratification of colorectal cancer screening by risk. ${ }^{109}$ Use of a PRS has also been proposed for the identification of individuals at increased risk of cardiovascular disease ${ }^{110}$ and Alzheimer's disease. ${ }^{111}$ A study of more than 81000 individuals published in August 2020 demonstrated that polygenic and monogenic risk factors interact with each other to modify risk in breast cancer, coronary artery disease and colon cancer. ${ }^{112}$ A selection of polygenic variants can influence the level of penetrance of the monogenic risk factor; consequently, a PRS can be used to predict the level of increased risk conferred by the monogenic risk variant carried by the individual.

While several lung cancer RPMs (including PLCO $_{\mathrm{M} 2012}$ ) consider family history of lung cancer as a risk factor, no widely used model includes a direct biological measure of genetic risk. Despite there not being a known common high-penetrance gene for lung cancer that could be integrated into an RPM (such as $B R C A 1 / 2$ in breast cancer, which is not associated with lung cancer ${ }^{113}$ ), there is evidence that a PRS of low-penetrance SNPs could have utility in lung cancer risk prediction and screening selection. The Young RPM, which was published in 2009, showed that including a PRS comprising of 20 SNPs associated with lung cancer risk increased the predictive ability of the RPM when compared with standard risk factors alone. ${ }^{114}$ However, the RPM was not externally validated in an independent population and had certain non-standardised study design elements. ${ }^{115}$ Two further studies demonstrated that the incorporation of individual genetic markers into lung cancer RPMs (Improved LLP and Expanded Spitz) improved predictive ability by modest amounts. ${ }^{116-118}$ Crucially, the development of all three of these models preceded the large-scale meta-analyses published in recent years, which provide the best evidence for which SNPs are most robustly associated with lung cancer risk in large and diverse populations. Consequently, while serving as important proofs of concept, these RPMs are of limited clinical utility.
More recent case-control studies again demonstrated that the inclusion of selected SNPs in models can improve lung cancer risk prediction. ${ }^{119-121}$ While these improvements were often too small to have a major benefit in the context of a screening programme, this is primarily a result of the small SNP panels tested. Successful PRS systems rely on the combination of a very large number of independent SNPs from a range of loci ${ }^{122}$; with the increase in meta-analyses of GWAS seen in the past few years (thereby increasing the pool of potentially predictive SNPs), the prospect of a successful integration of lung cancer risk predictive SNPs into a RPM becomes ever more possible.

In July 2019, a Chinese study reported the development of a 19 SNP PRS for the prediction of lung cancer risk that had been prospectively validated in a cohort of more than 95000 subjects. ${ }^{123}$ The study demonstrated that the PRS was better at lung cancer risk prediction than age and pack-year history alone; the $10 \%$ of the cohort with the highest genetic risk were 1.96 times more likely to develop lung cancer compared with the lowest risk $10 \%$. It also showed that light smokers at high genetic risk have comparable lung cancer risk with heavy smokers with intermediate genetic risk. Light smokers with low genetic risk had a similar lung cancer risk to non-smokers. The study found striking genetic heterogeneity between several lung cancer histological subgroups. It should be noted that this study did not test the PRS in an actual screening programme cohort, nor did it compare its predictive abilities with a full RPM. The PRS developed is also specific to a Chinese population. Despite these limitations, this study is the best demonstration yet of the utility of a PRS in lung cancer risk prediction.

\section{Next steps and implementation}

The successful, robust validation of a PRS for lung cancer, particularly one that was prospectively validated in such a large cohort, is an important milestone in the field. However, substantial research is required before such a tool will be ready for clinical use. As more samples and datasets become available from lung cancer screening trials and pilots around the world, opportunities will emerge to further validate and augment the list of SNPs thought to be associated with lung cancer risk. This will provide additional evidence to facilitate the construction of new PRS tools or to improve the tools presented in previous studies. The high-risk nature of individuals passing through screening programmes provides fertile ground for recruitment to nested case-control or case-cohort studies due to significant exposure to risk factors and different cancer outcomes. Machine learning approaches may also be useful in identifying SNPs associated with cancer risk, as well as more complex gene-gene interactions. ${ }^{124}$ It is important that this research be replicated in a wide variety of populations; many SNPs associated with lung cancer risk are specific to a particular ethnicity, necessitating the development of a PRS calibrated to the population it is intended to be used in. Developing PRS tools in diverse populations is important to ensure that the use of PRS in screening selection does not exacerbate health inequalities. ${ }^{125}$ Furthermore, many SNPs are associated with specific lung cancer histological subtypes. PRS construction must ensure that there is a sufficiently diverse array of SNPs on the panel to predict several types of lung cancer.

Following its construction, a PRS tool must be externally validated (ideally prospectively) in combination with the RPMs currently used in screening programmes to ensure that the PRS improves the predictive ability of the model. Some of the variables included in RPMs such as family history and tobacco smoke exposure might already be accounting for a portion of the 
risk impact conferred by genetic variants. Considering genetic risk factors in combination with demographic and lifestyle risk factors and testing them in an actual screening populations (such as has been done with the BOADICEA and Tyrer-Cuzick breast cancer RPMs ${ }^{126}{ }^{127}$ ) ensures that personal risk is not overestimated and that the genetic component of the RPM has independent utility in a screening selection context.

Once a PRS tool integrated into an RPM has been shown to improve predictive ability, practical considerations relating to clinical implementation must be considered. Several biomarker studies embedded within lung cancer screening trials and programmes have provided evidence for the acceptability of blood collection from participants within screening settings and that a pipeline for blood storage and transportation, as well as the subsequent extraction of DNA and genotyping, is feasible. ${ }^{128-130}$ While good proof of concept, only establishing a participant's PRS after their initial contact with the screening service means that it could not be used to inform screening eligibility at their initial assessment; the PRS could still be used to inform screening interval or to exclude low-risk individuals from further scans, but this limits the potential utility and effectiveness of the PRS. Asking participants to attend a separate clinic some time prior to screening for blood extraction would solve this issue but may reduce uptake and compliance among the target population. The genetic testing of saliva, rather than blood, could be an effective solution to this implementation challenge, as mailed collection kits can be returned by the participants for genotyping prior to any in-person contact with the screening service. Saliva collection has been shown to be acceptable to participants and a viable source of DNA for genotyping in several screening studies. ${ }^{131-133}$

Appropriate genetic counselling infrastructure must be implemented for PRS to become a routine tool for screening selection. An individual's understanding of disease risk in general, how polygenic factors influence their risk and what impact this knowledge has on health behaviour and anxiety are all important psychological considerations that need addressing prior to clinical implementation. Research examining patient interest in PRS testing in other disease areas has revealed broadly positive attitudes $^{134}{ }^{135}$; patients also seem to receive their genetic risk score without significant distress or anxiety and are able to recall the information accurately. ${ }^{136} 137$ Development of tools for counselling patients in polygenic risk is ongoing. ${ }^{138}$ This research will need to be replicated in lung cancer screening populations, particularly considering that those at high risk of lung cancer often live in deprived areas, have low educational attainment and may have limited health literacy. ${ }^{56}$

Ultimately, the routine adoption of a PRS tool within a lung screening programme will depend on its clinical impact and cost-effectiveness. An effective PRS might reduce the total number of people eligible for screening or reduce the frequency of screening. It might also favour the selection of those who have a lower smoking exposure and therefore a lower burden of comorbidity who have 'more to gain' from screening. ${ }^{139}$ To reduce the cost of the test, the PRS could be targeted at those close to the risk threshold (above and below) rather than being used more broadly. Formal cost-effectiveness analyses would be required to determine the best approach within the setting of a lung cancer screening programme, as has been performed in other disease areas. ${ }^{48} 140141$

\section{CONCLUSION}

In an editorial following the publication of the NELSON trial results, Duffy and Field state: 'With the NELSON results, the efficacy of low-dose CT screening for lung cancer is confirmed. Our job is no longer to assess whether low-dose CT screening for lung cancer works: it does. Our job is to identify the target population in which it will be acceptable and cost-effective. ${ }^{142}$ Research in recent years has demonstrated that genetic factors, in particular the development and integration of polygenic risk scores into risk prediction models, could play a crucial role in augmenting the identification of the target population for lung cancer screening. There is an urgent need to construct a PRS that demonstrably improves risk prediction in an actual screening cohort over-and-above current RPMs, in a variety of populations and for several lung cancer histological subtypes. This could result in a lower rate of overdiagnosis and false-positive results in future screening programmes ${ }^{39} 143$ as well as their improved efficiency. Supplementary studies relating to the practical implementation of genetic testing in a lung cancer screening setting (including cost-effectiveness analysis and patient acceptability) will become important as the field develops further.

Twitter Mikey B Lebrett @mlebrett, Emma J Crosbie @DrEmmaCrosbie and Emma RWoodward @ER_Woodward

Contributors Original draft preparation: MBL. Review and editing: all authors. Guarantor of overall content: PAJC.

Funding MBL, PAJC, EJC, MJS, ERW and DGE are supported by the NIHR Manchester Biomedical Research Centre.

Competing interests None declared.

\section{Patient consent for publication Not required.}

Open access This is an open access article distributed in accordance with the Creative Commons Attribution 4.0 Unported (CC BY 4.0) license, which permits others to copy, redistribute, remix, transform and build upon this work for any purpose, provided the original work is properly cited, a link to the licence is given, and indication of whether changes were made. See: https://creativecommons.org/ licenses/by/4.01.

\section{ORCID iDs}

Mikey B Lebrett http://orcid.org/0000-0002-5386-9987

Emma J Crosbie http://orcid.org/0000-0003-0284-8630

Miriam J Smith http://orcid.org/0000-0002-3184-0817

Emma R Woodward http://orcid.org/0000-0002-6297-2855

D Gareth Evans http://orcid.org/0000-0002-8482-5784

Philip A J Crosbie http://orcid.org/0000-0001-8941-4813

\section{REFERENCES}

1 Bray F, Ferlay J, Soerjomataram I, Siegel RL, Torre LA, Jemal A. Global cancer statistics 2018: GLOBOCAN estimates of incidence and mortality worldwide for 36 cancers in 185 countries. CA Cancer J Clin 2018;68:394-424.

2 Cancer Research UK. Lung cancer statistics. Available: https://www. cancerresearchuk.org/health-professional/cancer-statistics/statistics-by-cancer-type/ lung-cancer\#heading-Two [Accessed 15 Oct 2018].

3 Cancer Research UK. Cancer mortality for common cancers. Available: https://www. cancerresearchuk.org/health-professional/cancer-statistics/mortality/commoncancers-compared\#ref- [Accessed 18 Oct 2018].

4 Gridelli C, Rossi A, Carbone DP, Guarize J, Karachaliou N, Mok T, Petrella F, Spaggiari L, Rosell R. Non-Small-Cell lung cancer. Nat Rev Dis Primers 2015;1.

5 Sher T, Dy GK, Adjei AA. Small cell lung cancer. Mayo Clinic Proceedings 2008:83:355-67.

6 Brown KF, Rumgay H, Dunlop C, Ryan M, Quartly F, Cox A, Deas A, Elliss-Brookes L, Gavin A, Hounsome L, Huws D, Ormiston-Smith N, Shelton J, White C, Parkin DM. The fraction of cancer attributable to modifiable risk factors in England, Wales, Scotland, Northern Ireland, and the United Kingdom in 2015. Br J Cancer 2018;118:1130-41.

7 Parkin DM. 2. Tobacco-attributable cancer burden in the UK in 2010. Br J Cancer 2011;105:S6-13.

8 Tammemägi MC, Katki HA, Hocking WG, Church TR, Caporaso N, Kvale PA, Chaturvedi AK, Silvestri GA, Riley TL, Commins J, Berg CD. Selection criteria for lungcancer screening. N Engl J Med 2013;368:728-36.

9 Cancer Research UK. Lung cancer incidence statistics. Available: https://www. cancerresearchuk.org/health-professional/cancer-statistics/statistics-by-cancer-type/ lung-cancer/incidence\#heading-Two [Accessed 29 Oct 2018]

10 World Health Organization. Who Handbook on indoor radon a public health perspective, 2009. Available: http://apps.who.int/iris/bitstream/handle/10665/44149/ 
9789241547673_eng.pdf;;sessionid=C70F2996715CF9A39A0FA2E2B9D2BC8A? sequence $=1$ [Accessed 23 Oct 2018].

11 Hovanec J, Siemiatycki J, Conway DI, Olsson A, Stücker I, Guida F, Jöckel K-H, Pohlabeln H, Ahrens W, Brüske I, Wichmann H-E, Gustavsson P, Consonni D, Merletti F, Richiardi L, Simonato L, Fortes C, Parent M-E, McLaughlin J, Demers P, Landi MT, Caporaso N, Tardón A, Zaridze D, Szeszenia-Dabrowska N, Rudnai P, Lissowska J, Fabianova E, Field J, Dumitru RS, Bencko V, Foretova L, Janout V, Kromhout H, Vermeulen R, Boffetta P, Straif K, Schüz J, Kendzia B, Pesch B, Brüning T, Behrens T. Lung cancer and socioeconomic status in a pooled analysis of case-control studies. PLoS One 2018;13:e0192999.

12 Dracham CB, Shankar A, Madan R. Radiation induced secondary malignancies: a review article. Radiat Oncol J 2018:36:85-94.

13 Brenner DR, McLaughlin JR, Hung RJ. Previous lung diseases and lung cancer risk: a systematic review and meta-analysis. PLoS One 2011;6:e17479.

14 Denholm R, Schüz J, Straif K, Stücker I, Jöckel K-H, Brenner DR, De Matteis S, Boffetta P, Guida F, Brüske I, Wichmann H-E, Landi MT, Caporaso N, Siemiatycki J, Ahrens W, Pohlabeln H, Zaridze D, Field JK, McLaughlin J, Demers P, Szeszenia-Dabrowska N, Lissowska J, Rudnai P, Fabianova E, Dumitru RS, Bencko V, Foretova L, Janout V, Kendzia B, Peters S, Behrens T, Vermeulen R, Brüning T, Kromhout H, C Olsson A. Is previous respiratory disease a risk factor for lung cancer? Am J Respir Crit Care Med 2014;190:549-59.

15 Brenner DR, Boffetta P, Duell EJ, Bickeböller H, Rosenberger A, McCormack V, Muscat JE, Yang P, Wichmann H-E, Brueske-Hohlfeld I, Schwartz AG, Cote ML, Tjønneland A, Friis S, Le Marchand L, Zhang Z-F, Morgenstern H, Szeszenia-Dabrowska N, Lissowska J, Zaridze D, Rudnai P, Fabianova E, Foretova L, Janout V, Bencko V, Schejbalova M, Brennan P, Mates IN, Lazarus P, Field JK, Raji O, McLaughlin JR, Liu G, Wiencke J, Neri M, Ugolini D, Andrew AS, Lan Q, Hu W, Orlow I, Park BJ, Hung RJ. Previous lung diseases and lung cancer risk: a pooled analysis from the International lung cancer Consortium. Am J Epidemiol 2012;176:573-85.

16 Koshiol J, Rotunno M, Consonni D, Pesatori AC, De Matteis S, Goldstein AM, Chaturvedi AK, Wacholder S, Landi MT, Lubin JH, Caporaso NE. Lower risk of lung cancer after multiple pneumonia diagnoses. Cancer Epidemiol Biomarkers Prev 2010;19:716-21.

17 Liang H-Y, Li X-L, Yu X-S, Guan P, Yin Z-H, He Q-C, Zhou B-S. Facts and fiction of the relationship between preexisting tuberculosis and lung cancer risk: a systematic review. Int J Cancer 2009;125:2936-44.

18 Matakidou A, Eisen T, Houlston RS. Systematic review of the relationship between family history and lung cancer risk. Br J Cancer 2005;93:825-33.

19 Malkin D. Li-Fraumeni syndrome. Genes Cancer 2011:2:475-84.

20 Ohtsuka K, Ohnishi H, Kurai D, Matsushima S, Morishita Y, Shinonaga M, Goto H, Watanabe T. Familial lung adenocarcinoma caused by the EGFR V843I germ-line mutation. J Clin Oncol 2011;29:e191-2.

21 Gasperino J. Gender is a risk factor for lung cancer. Med Hypotheses 2011;76:328-31.

22 Stapelfeld C, Dammann C, Maser E. Sex-Specificity in lung cancer risk. Int I Cancer 2020;146:2376-82

23 Cassidy A, Myles JP, van Tongeren M, Page RD, Liloglou T, Duffy SW, Field JK. The LLP risk model: an individual risk prediction model for lung cancer. $\mathrm{Br} J$ Cancer 2008:98:270-6.

24 Office for National Statistics. Cancer survival in England - adults diagnosed. Available: https://www.ons.gov.uk/peoplepopulationandcommunity/ healthandsocialcare/conditionsanddiseases/datasets/cancersurvivalratescancersur vivalinenglandadultsdiagnosed [Accessed 2 Jun 2020].

25 Cancer Research UK. Lung cancer survival statistics. Available: https://www. cancerresearchuk.org/health-professional/cancer-statistics/statistics-by-cancer-type/ lung-cancer/survival\#collapseTwo [Accessed 2 Jun 2020].

26 Quaresma M, Coleman MP, Rachet B. 40-Year trends in an index of survival for all cancers combined and survival adjusted for age and sex for each cancer in England and Wales, 1971-2011: a population-based study. The Lancet 2015;385:1206-18.

27 Cancer Research UK. Lung cancer incidence statistics. Available: https://www. cancerresearchuk.org/health-professional/cancer-statistics/statistics-by-cancer-type/ lung-cancer/incidence\#heading-Three [Accessed 3 Nov 2020].

28 Office for National Statistics. Cancer survival by stage at diagnosis for England (experimental statistics). Available: https://www.ons.gov.uk/peoplepopulationandc ommunity/healthandsocialcare/conditionsanddiseases/bulletins/cancersurvivalbystag eatdiagnosisforenglandexperimentalstatistics/adultsdiagnosed20122013and2014an dfollowedupto2015 [Accessed 16 Oct 2018].

29 Rami-Porta R, Bolejack V, Crowley J, Ball D, Kim J, Lyons G, Rice T, Suzuki K, Thomas CF, Travis WD, Wu Y-L, IASLC Staging and Prognostic Factors Committee, Advisory Boards and Participating Institutions. The IASLC lung cancer staging project: proposals for the revisions of the T descriptors in the forthcoming eighth edition of the TNM classification for lung cancer. I Thorac Oncol 2015;10:990-1003.

30 Birring SS, Peake MD. Symptoms and the early diagnosis of lung cancer. Thorax 2005;60:268-9.

31 Manser R, Irving LB, Stone C, Byrnes G, Abramson MJ, Campbell D. Screening for lung cancer. In: Manser R, ed. Cochrane database of systematic reviews. Chichester, UK: John Wiley \& Sons, Ltd, 2004: CD001991.
32 Oken MM, Hocking WG, Kvale PA, Andriole GL, Buys SS, Church TR, Crawford ED, Fouad MN, Isaacs C, Reding DJ, Weissfeld JL, Yokochi LA, O'Brien B, Ragard LR, Rathmell JM, Riley TL, Wright P, Caparaso N, Hu P, Izmirlian G, Pinsky PF, Prorok PC, Kramer BS, Miller AB, Gohagan JK, Berg CD. Screening by chest radiograph and lung cancer mortality: the prostate, lung, colorectal, and ovarian (PLCO) randomized trial. JAMA - J Am Med Assoc 2011:306:1865-73.

33 Kaneko M, Eguchi K, Ohmatsu H, Kakinuma R, Naruke T, Suemasu K, Moriyama N. Peripheral lung cancer: screening and detection with low-dose spiral CT versus radiography. Radiology 1996;201:798-802.

34 Henschke Cl, Yankelevitz DF, Libby DM, Pasmantier MW, Smith JP, Miettinen OS, International Early Lung Cancer Action Program Investigators,. Survival of patients with stage I lung cancer detected on CT screening. N Eng/ J Med 2006;355:1763-71.

35 Aberle DR, Adams AM, Berg CD, Black WC, Clapp JD, Fagerstrom RM, Gareen IF, Gatsonis C, Marcus PM, Sicks JD, National Lung Screening Trial Research Team TNLSTR, Reduced lung-cancer mortality with low-dose computed tomographic screening. N Eng/ J Med 2011;365:395-409.

36 de Koning $\mathrm{HJ}$, van der Aalst CM, de Jong PA, Scholten ET, Nackaerts K, Heuvelmans MA, Lammers J-WJ, Weenink C, Yousaf-Khan U, Horeweg N, van 't Westeinde S, Prokop M, Mali WP, Mohamed Hoesein FAA, van Ooijen PMA, Aerts JGJV, den Bakker MA, Thunnissen E, Verschakelen J, Vliegenthart R, Walter JE, ten Haaf K, Groen HJM, Oudkerk M. Reduced lung-cancer mortality with volume CT screening in a randomized trial. N Engl J Med Overseas Ed 2020:382:503-13.

37 Becker N, Motsch E, Trotter A, Heussel CP, Dienemann H, Schnabel PA, Kauczor H-U, Maldonado SG, Miller AB, Kaaks R, Delorme S. Lung cancer mortality reduction by LDCT screening-Results from the randomized German LUSI trial. Int J Cancer 2020;146:1503-13.

38 Pastorino U, Silva M, Sestini S, Sabia F, Boeri M, Cantarutti A, Sverzellati N, Sozzi G, Corrao G, Marchianò A. Prolonged lung cancer screening reduced 10-year mortality in the mild trial: new confirmation of lung cancer screening efficacy. Ann Oncol 2019:30:1162-9.

39 Welch HG, Black WC. Overdiagnosis in cancer. J Natl Cancer Inst 2010;102:605-13.

40 Marcus PM, Bergstralh EJ, Zweig MH, Harris A, Offord KP, Fontana RS. Extended lung cancer incidence follow-up in the Mayo lung project and overdiagnosis. J Natl Cancer Inst 2006;98:748-56.

41 Patz EF, Pinsky P, Gatsonis C, Sicks JD, Kramer BS, Tammemägi MC, Chiles C, Black WC, Aberle DR. Overdiagnosis in low-dose computed tomography screening for lung cancer. JAMA Intern Med 2014:174:269-74.

42 National Lung Screening Trial Research Team. Lung cancer incidence and mortality with extended follow-up in the National lung screening trial. J Thorac Oncol 2019;14:1732-42.

43 Tosteson ANA, Fryback DG, Hammond CS, Hanna LG, Grove MR, Brown M, Wang Q, Lindfors K, Pisano ED. Consequences of false-positive screening mammograms. JAMA Intern Med 2014;174:954-61.

44 Rasmussen JF, Siersma V, Malmqvist J, Brodersen J. Psychosocial consequences of false positives in the Danish lung cancer CT screening trial: a nested matched cohort study. BMJ Open 2020;10:34682

45 Brodersen J, Siersma VD. Long-Term psychosocial consequences of false-positive screening mammography. Ann Fam Med 2013;11:106-15.

46 Heerink WJ, de Bock GH, de Jonge GJ, Groen HJM, Vliegenthart R, Oudkerk M. Complication rates of CT-guided transthoracic lung biopsy: meta-analysis. Eur Radiol 2017;27:138-48.

47 Rampinelli C, De Marco P, Origgi D, Maisonneuve P, Casiraghi M, Veronesi G, Spaggiari L, Bellomi M. Exposure to low dose computed tomography for lung cancer screening and risk of cancer: secondary analysis of trial data and risk-benefit analysis. BMJ 2017;356:347.

48 Pashayan N, Morris S, Gilbert FJ, Pharoah PDP. Cost-Effectiveness and Benefit-toHarm ratio of risk-stratified screening for breast cancer: a life-table model. JAMA Oncol 2018;4:1504-10.

49 Kovalchik SA, Tammemagi M, Berg CD, Caporaso NE, Riley TL, Korch M, Silvestri GA, Chaturvedi AK, Katki HA. Targeting of low-dose CT screening according to the risk of lung-cancer death. N Engl J Med 2013:369:245-54.

50 Marcus MW, Raji OY, Field JK. Lung cancer screening: identifying the high risk cohort. J Thorac Dis 2015;7:S156-62

51 Hüsing A, Kaaks R. Risk prediction models versus simplified selection criteria to determine eligibility for lung cancer screening: an analysis of German federal-wide survey and incidence data. Eur J Epidemiol 2020;35:899-912

52 Tammemägi MC. Selecting lung cancer screenees using risk prediction modelswhere do we go from here. Transl Lung Cancer Res 2018;7:243-53.

53 Field JK, Duffy SW, Baldwin DR, Brain KE, Devaraj A, Eisen T, Green BA, Holemans JA, Kavanagh T, Kerr KM, Ledson M, Lifford KJ, McRonald FE, Nair A, Page RD, Parmar MKB, Rintoul RC, Screaton N, Wald NJ, Weller D, Whynes DK, Williamson PR, Yadegarfar G, Hansell DM. The UK lung cancer screening trial: a pilot randomised controlled trial of low-dose computed tomography screening for the early detection of lung cancer. Health Technol Assess 2016;20:1-146.

54 Weber M, Yap S, Goldsbury D, Manners D, Tammemagi M, Marshall H, Brims F, McWilliams A, Fong K, Kang YJ, Caruana M, Banks E, Canfell K. Identifying high risk individuals for targeted lung cancer screening: Independent validation of the PLCO m2012 risk prediction tool. Int J Cancer 2017;141:242-53. 
55 Tammemägi MC, Church TR, Hocking WG, Silvestri GA, Kvale PA, Riley TL, Commins J, Berg CD. Evaluation of the lung cancer risks at which to screen ever- and never-smokers: screening rules applied to the PLCO and NLST cohorts. PLOS Med 2014;11:e1001764.

56 Crosbie PA, Balata H, Evison M, Atack M, Bayliss-Brideaux V, Colligan D, Duerden R, Eaglesfield J, Edwards T, Elton P, Foster J, Greaves M, Hayler G, Higgins C, Howells J, Irion K, Karunaratne D, Kelly J, King Z, Manson S, Mellor S, Miller D, Myerscough A, Newton T, O'Leary M, Pearson R, Pickford J, Sawyer R, Screaton NJ, Sharman A Simmons M, Smith E, Taylor B, Taylor S, Walsham A, Watts A, Whittaker J, Yarnell L, Threlfall A, Barber PV, Tonge J, Booton R. Implementing lung cancer screening: baseline results from a community-based 'Lung Health Check' pilot in deprived areas of Manchester. Thorax 2019;74:405-9.

57 Crosbie PA, Balata H, Evison M, Atack M, Bayliss-Brideaux V, Colligan D, Duerden R, Eaglesfield J, Edwards T, Elton P, Foster J, Greaves M, Hayler G, Higgins C, Howells J, Irion K, Karunaratne D, Kelly J, King Z, Lyons J, Manson S, Mellor S, Miller D, Myerscough A, Newton T, O'Leary M, Pearson R, Pickford J, Sawyer R, Screaton NJ, Sharman A, Simmons M, Smith E, Taylor B, Taylor S, Walsham A, Watts A, Whittaker J, Yarnell L, Threlfall A, Barber PV, Tonge J, Booton R. Second round results from the Manchester 'Lung Health Check' community-based targeted lung cancer screening pilot. Thorax 2019:74:700-4.

58 Lebrett MB, Balata H, Evison M, Colligan D, Duerden R, Elton P, Greaves M, Howells J, Irion K, Karunaratne D, Lyons J, Mellor S, Myerscough A, Newton T, Sharman A, Smith E, Taylor B, Taylor S, Walsham A, Whittaker J, Barber PV, Tonge J, Robbins HA, Booton $\mathrm{R}$, Crosbie PAJ. Analysis of lung cancer risk model $\left(\mathrm{PLCO}_{\mathrm{M} 2012}\right.$ and $\left.\mathrm{LLP}_{\mathrm{v2}}\right)$ performance in a community-based lung cancer screening programme. Thorax 2020;75:661-8.

59 NHS. Targeted screening for lung cancer with low radiation dose computed tomography standard protocol prepared for the targeted lung health checks programme. Available: www.england.nhs.uk/cancer [Accessed 11 Jun2019].

60 Pirie K, Peto R, Reeves GK, Green J, Beral V. The 21 st century hazards of smoking and benefits of stopping: a prospective study of one million women in the UK. The Lancet 2013;381:133-41.

61 Reitsma M, Kendrick P, Anderson J, Arian N, Feldman R, Gakidou E, Gupta V. Reexamining rates of decline in lung cancer risk after smoking cessation. A metaanalysis. Ann Am Thorac Soc 2020;17:1126-32.

62 Tindle HA, Stevenson Duncan M, Greevy RA, Vasan RS, Kundu S, Massion PP, Freiberg MS. Lifetime smoking history and risk of lung cancer: results from the Framingham heart study. J Nat/ Cancer Inst 2018;110.

63 Lowsky DJ, Olshansky SJ, Bhattacharya J, Goldman DP. Heterogeneity in healthy aging. J Gerontol A Biol Sci Med Sci 2014;69:640-9.

64 Jylhävä J, Pedersen NL, Hägg S. Biological age predictors. EBioMedicine 2017;21:29-36.

65 Tokuhata GK, Lilienfeld AM. Familial aggregation of lung cancer among hospital patients. Public Health Reports 1963;78:277-83.

66 Coté ML, Liu M, Bonassi S, Neri M, Schwartz AG, Christiani DC, Spitz MR, Muscat JE, Rennert G, Aben KK, Andrew AS, Bencko V, Bickeböller H, Boffetta P, Brennan P, Brenner $H$, Duell EJ, Fabianova E, Field JK, Foretova L, Friis S, Harris CC, Holcatova I, Hong Y-C, Isla D, Janout V, Kiemeney LA, Kiyohara C, Lan Q, Lazarus P, Lissowska J, Le Marchand L, Mates D, Matsuo K, Mayordomo JI, McLaughlin JR, Morgenstern H, Müeller H, Orlow I, Park BJ, Pinchev M, Raji OY, Rennert HS, Rudnai P, Seow A, Stucker I, Szeszenia-Dabrowska N, Dawn Teare M, Tjønnelan A, Ugolini D, van der Heijden HFM, Wichmann E, Wiencke JK, Woll PJ, Yang P, Zaridze D, Zhang Z-F, Etzel CJ, Hung RJ. Increased risk of lung cancer in individuals with a family history of the disease: a pooled analysis from the International lung cancer Consortium. Eur J Cancer 2012;48:1957-68

67 Jonsson S, Thorsteinsdottir U, Gudbjartsson DF, Jonsson HH, Kristjansson K, Arnason S, Gudnason V, Isaksson HJ, Hallgrimsson J, Gulcher JR, Amundadottir LT, Kong A, Stefansson K. Familial risk of lung carcinoma in the Icelandic population. JAMA 2004;292.

68 AH W, Fontham ET, Reynolds P, Greenberg RS, Buffler P, Liff J, Boyd P, Correa P. Family history of cancer and risk of lung cancer among lifetime nonsmoking women in the United States. Am J Epidemio/ 1996;143:535-42.

69 Schwartz AG, Yang P, Swanson GM. Familial risk of lung cancer among nonsmokers and their relatives. Am J Epidemiol 1996;144:554-62.

70 Li X, Hemminki K. Inherited predisposition to early onset lung cancer according to histological type. Int J Cancer 2004;112:451-7.

71 Li X, Hemminki K. Familial multiple primary lung cancers: a population-based analysis from Sweden. Lung Cancer 2005;47:301-7.

72 Gaughan EM, Cryer SK, Yeap BY, Jackman DM, Costa DB. Family history of lung cancer in never smokers with non-small-cell lung cancer and its association with tumors harboring EGFR mutations. Lung Cancer 2013;79:193-7.

73 Mucci LA, Hjelmborg JB, Harris JR, Czene K, Havelick DJ, Scheike T, Graff RE, Holst K, Möller S, Unger RH, McIntosh C, Nuttall E, Brandt I, Penney KL, Hartman M, Kraft P, Parmigiani G, Christensen K, Koskenvuo M, Holm NV, Heikkilä K, Pukkala E, Skytthe A, Adami H-O, Kaprio J, for the Nordic Twin Study of Cancer (NorTwinCan) Collaboration. Familial risk and heritability of cancer among twins in Nordic countries. JAMA 2016;315:68-76.
74 Torkamani A, Wineinger NE, Topol EJ. The personal and clinical utility of polygenic risk scores. Nat Rev Genet 2018;19:581-90.

75 Schneider K, Zelley K, Nichols KE, Garber J. Li-Fraumeni Syndrome. 1999 Jan 19 [updated 2013 Apr 11]. University of Washington, Seattle; 1993-2019, 2019. Available: https://www.ncbi.nlm.nih.gov/books/NBK1311/ [Accessed 13 Aug 2020].

76 Li FP, Fraumeni JF. Soft-Tissue sarcomas, breast cancer, and other neoplasms. A familial syndrome? Ann Intern Med 1969;71:747-52.

77 Lynch HT, McComb RD, Osborn NK, Wolpert PA, Lynch JF, Wszolek ZK, Sidransky D, Steg RE. Predominance of brain tumors in an extended Li-Fraumeni (SBLA) kindred including a case of Sturge-Weber syndrome. Cancer 2000;88:433-9.

78 Yamamoto H, Yatabe Y, Toyooka S. Inherited lung cancer syndromes targeting never smokers. Trans/ Lung Cancer Res 2018;7:498-504.

79 Yu HA, Arcila ME, Harlan Fleischut M, Stadler Z, Ladanyi M, Berger MF, Robson M, Riely GJ. Germline EGFR T790M mutation found in multiple members of a familial cohort. J Thorac Oncol 2014;9:554-8.

80 Suda K, Onozato R, Yatabe Y, Mitsudomi T. Egfr T790M mutation: a double role in lung cancer cell survival? J Thorac Oncol 2009;4:1-4.

81 Bailey-Wilson JE, Sellers TA, Elston RC, Evens CC, Rothschild $H$. Evidence for a major gene effect in early-onset lung cancer. J La State Med Soc 1993;145:157-62.

82 Yang P, Schwartz AG, McAllister AE, Swanson GM, Aston CE. Lung cancer risk in families of nonsmoking probands: heterogeneity by age at diagnosis. Genet Epidemiol 1999:17:253-73.

83 Wu P-F, Lee C-H, Wang M-J, Goggins WB, Chiang T-A, Huang M-S, Ko Y-C, PF W, YC $K$. Cancer aggregation and complex segregation analysis of families with female non-smoking lung cancer probands in Taiwan. Eur J Cancer 2004;40:260-6.

84 Bailey-Wilson JE, Amos Cl, Pinney SM, Petersen GM, de Andrade M, Wiest JS, Fain P, Schwartz AG, You M, Franklin W, Klein C, Gazdar A, Rothschild H, Mandal D, Coons T, Slusser J, Lee J, Gaba C, Kupert E, Perez A, Zhou X, Zeng D, Liu Q, Zhang Q, Seminara D, Minna J, Anderson MW. A major lung cancer susceptibility locus maps to chromosome 6q23-25. Am J Hum Genet 2004;75:460-74.

85 Amos Cl, Pinney SM, Li Y, Kupert E, Lee J, de Andrade MA, Yang P, Schwartz AG, Fain PR, Gazdar A, Minna J, Wiest JS, Zeng D, Rothschild H, Mandal D, You M, Coons T, Gaba C, Bailey-Wilson JE, Anderson MW. A susceptibility locus on chromosome $6 q$ greatly increases lung cancer risk among light and never smokers. Cancer Res 2010;70:2359-67.

86 You $M$, Wang D, Liu P, Vikis $H$, James $M$, Lu Y, Wang Y, Wang $M$, Chen Q, Jia D, Liu Y, Wen W, Yang P, Sun Z, Pinney SM, Zheng W, Shu X-O, Long J, Gao Y-T, Xiang Y-B, Chow W-H, Rothman N, Petersen GM, de Andrade M, Wu Y, Cunningham JM, Wiest JS, Fain PR, Schwartz AG, Girard L, Gazdar A, Gaba C, Rothschild H, Mandal D, Coons T, Lee J, Kupert E, Seminara D, Minna J, Bailey-Wilson JE, Amos $\mathrm{Cl}$, Anderson MW. Fine Mapping of Chromosome 6q23-25 Region in Familial Lung Cancer Families Reveals RGS17 as a Likely Candidate Gene. Clin Cancer Res 2009:15:2666-74.

87 James MA, Lu Y, Liu Y, Vikis HG, You M, Michael AJ, Liu Y, Haris GV. RGS17, an overexpressed gene in human lung and prostate cancer, induces tumor cell proliferation through the cyclic AMP-PKA-CREB pathway. Cancer Res 2009;69:2108-16.

88 Chen H-Y, Yu S-L, Ho B-C, Su K-Y, Hsu Y-C, Chang C-S, Li Y-C, Yang S-Y, Hsu P-Y, Ho H, Chang Y-H, Chen C-Y, Yang H-I, Hsu C-P, Yang T-Y, Chen K-C, Hsu K-H, Tseng J-S, Hsia J-Y, Chuang C-Y, Yuan S, Lee M-H, Liu C-H, Wu G-I, Hsiung CA, Chen Y-M, Wang C-L, Huang M-S, Yu C-J, Chen K-Y, Tsai Y-H, Su W-C, Chen H-W, Chen JJW, Chen C-J, Chang G-C, Yang P-C, Li K-C, SL Y, BC H, KY S, YC L, Hsu PY, Chen KC, Sen TJ, GI W, CJ Y, WC S, KC L. R331W missense mutation of oncogene Yap1 is a germline risk allele for lung adenocarcinoma with medical actionability. J Clin Oncol 2015:33:2303-10.

89 Xiong D, Wang Y, Kupert E, Simpson C, Pinney SM, Gaba CR, Mandal D, Schwartz AG, Yang P, de Andrade M, Pikielny C, Byun J, Li Y, Stambolian D, Spitz MR, Liu Y, Amos Cl, Bailey-Wilson JE, Anderson M, You M. A recurrent mutation in PARK2 is associated with familial lung cancer. Am J Hum Genet 2015;96:301-8.

90 gnomAD. Single nucleotide variant: 6-162206852-G-A (GRCh37). Available: https:// gnomad.broadinstitute.org/variant/6-162206852-G-A?dataset=gnomad_r2_1 [Accessed 23 Jul2020].

91 Bossé Y, Amos Cl. A decade of GWAS results in lung cancer. Cancer Epidemiol Biomarkers Prev 2018;27:363-79.

92 loannidis JP, Boffetta P, Little J, O'Brien TR, Uitterlinden AG, Vineis P, Balding DJ, Chokkalingam A, Dolan SM, Flanders WD, Higgins JP, McCarthy MI, McDermott DH, Page GP, Rebbeck TR, Seminara D, Khoury MJ. Assessment of cumulative evidence on genetic associations: interim guidelines. Int J Epidemiol 2008;37:120-32.

93 Wang J, Liu Q, Yuan S, Xie W, Liu Y, Xiang Y, Wu N, Wu L, Ma X, Cai T, Zhang Y, Sun $Z$, Li Y. Genetic predisposition to lung cancer: comprehensive literature integration, meta-analysis, and multiple evidence assessment of candidate-gene association studies. Sci Rep 2017;7:8371.

94 Liu C, Cui H, Gu D, Zhang M, Fang Y, Chen S, Tang M, Zhang B, Chen H. Genetic polymorphisms and lung cancer risk: evidence from meta-analyses and genomewide association studies. Lung Cancer 2017;113:18-29.

95 Wacholder S, Chanock S, Garcia-Closas M, El ghormli L, Rothman N. Assessing the probability that a positive report is false: an approach for molecular epidemiology studies. J Nat/ Cancer Inst 2004;96:434-42. 
96 McKay JD, Hung RJ, Han Y, Zong X, Carreras-Torres R, Christiani DC, Caporaso NE, Johansson M, Xiao X, Li Y, Byun J, Dunning A, Pooley KA, Qian DC, Ji X, Liu G, Timofeeva MN, Bojesen SE, Wu X, Le Marchand L, Albanes D, Bickeböller H, Aldrich MC, Bush WS, Tardon A, Rennert G, Teare MD, Field JK, Kiemeney LA, Lazarus P, Haugen A, Lam S, Schabath MB, Andrew AS, Shen H, Hong Y-C, Yuan J-M, Bertazzi PA, Pesatori AC, Ye Y, Diao N, Su L, Zhang R, Brhane Y, Leighl N, Johansen JS, Mellemgaard A, Saliba W, Haiman CA, Wilkens LR, Fernandez-Somoano A, Fernandez-Tardon G, van der Heijden HFM, Kim JH, Dai J, Hu Z, Davies MPA, Marcus MW, Brunnström H, Manjer J, Melander O, Muller DC, Overvad K, Trichopoulou A, Tumino R, Doherty JA, Barnett MP, Chen C, Goodman GE, Cox A, Taylor F, Woll P, Brüske I, Wichmann H-E, Manz J, Muley TR, Risch A, Rosenberger A, Grankvist K, Johansson M, Shepherd FA, Tsao M-S, Arnold SM, Haura EB, Bolca C, Holcatova I, Janout V, Kontic M, Lissowska J, Mukeria A, Ognjanovic S, Orlowski TM, Scelo G, Swiatkowska B, Zaridze D, Bakke P, Skaug V, Zienolddiny S, Duell EJ, Butler LM, Koh W-P, Gao Y-T, Houlston RS, McLaughlin J, Stevens VL, Joubert P, Lamontagne M, Nickle DC, Obeidat Ma'en, Timens W, Zhu B, Song L, Kachuri L, Artigas MS, Tobin MD, Wain LV, Rafnar T, Thorgeirsson TE, Reginsson GW, Stefansson K, Hancock DB, Bierut LJ, Spitz MR, Gaddis NC, Lutz SM, Gu F, Johnson EO, Kamal A, Pikielny C, Zhu $D$, Lindströem S, Jiang $X$, Tyndale RF, Chenevix-Trench G, Beesley J, Bossé $Y$, Chanock S, Brennan P, Landi MT, Amos Cl, SpiroMeta Consortium. Large-Scale association analysis identifies new lung cancer susceptibility loci and heterogeneity in genetic susceptibility across histological subtypes. Nat Genet 2017:49:1126-32.

97 Chen L-S, Baker T, Hung RJ, Horton A, Culverhouse R, Hartz S, Saccone N, Cheng I, Deng B, Han Y, Hansen HM, Horsman J, Kim C, Rosenberger A, Aben KK, Andrew AS, Chang S-C, Saum K-U, Dienemann H, Hatsukami DK, Johnson EO, Pande M, Wrensch MR, McLaughlin J, Skaug V, van der Heijden EH, Wampfler J, Wenzlaff A, Woll P, Zienolddiny S, Bickeböller H, Brenner H, Duell EJ, Haugen A, Brüske I, Kiemeney LA, Lazarus P, Le Marchand L, Liu G, Mayordomo J, Risch A, Schwartz AG, Teare MD, Wu X, Wiencke JK, Yang P, Zhang Z-F, Spitz MR, Amos Cl, Bierut LJ. Genetic risk can be decreased: quitting smoking decreases and delays lung cancer for smokers with high and low CHRNA5 risk genotypes - a meta-analysis. EBioMedicine 2016:11:219-26.

98 Improgo MRD, Scofield MD, Tapper AR, Gardner PD. From smoking to lung cancer: the CHRNA5/A3/B4 connection. Oncogene 2010;29:4874-84.

99 Saccone SF, Hinrichs AL, Saccone NL, Chase GA, Konvicka K, Madden PAF, Breslau N, Johnson EO, Hatsukami D, Pomerleau O, Swan GE, Goate AM, Rutter J, Bertelsen S, Fox L, Fugman D, Martin NG, Montgomery GW, Wang JC, Ballinger DG, Rice JP, Bierut LJ. Cholinergic nicotinic receptor genes implicated in a nicotine dependence association study targeting 348 candidate genes with 3713 SNPs. Hum Mol Genet 2007;16:36-49.

100 Hung RJ, McKay JD, Gaborieau V, Boffetta P, Hashibe M, Zaridze D, Mukeria A Szeszenia-Dabrowska N, Lissowska J, Rudnai P, Fabianova E, Mates D, Bencko V Foretova L, Janout V, Chen C, Goodman G, Field JK, Liloglou T, Xinarianos G, Cassidy A, McLaughlin J, Liu G, Narod S, Krokan HE, Skorpen F, Elvestad MB, Hveem K, Vatten L, Linseisen J, Clavel-Chapelon F, Vineis P, Bueno-de-Mesquita HB, Lund E, Martinez C, Bingham S, Rasmuson T, Hainaut P, Riboli E, Ahrens W, Benhamou S, Lagiou P, Trichopoulos D, Holcátová I, Merletti F, Kjaerheim K, Agudo A, Macfarlane G, Talamini R, Simonato L, Lowry R, Conway DI, Znaor A, Healy C, Zelenika D, Boland A, Delepine M, Foglio M, Lechner D, Matsuda F, Blanche H, Gut I, Heath S, Lathrop M, Brennan P. A susceptibility locus for lung cancer maps to nicotinic acetylcholine receptor subunit genes on 15q25. Nature 2008;452:633-7.

101 Amos CI, Wu X, Broderick P, Gorlov IP, Gu J, Eisen T, Dong Q, Zhang Q, Gu X, Vijayakrishnan J, Sullivan K, Matakidou A, Wang Y, Mills G, Doheny K, Tsai Y-Y, Chen WV, Shete S, Spitz MR, Houlston RS. Genome-Wide association scan of tag SNPs identifies a susceptibility locus for lung cancer at 15q25.1. Nat Genet 2008;40:616-22

102 Liu P, Vikis HG, Wang D, Lu Y, Wang Y, Schwartz AG, Pinney SM, Yang P, de Andrade M, Petersen GM, Wiest JS, Fain PR, Gazdar A, Gaba C, Rothschild H, Mandal D, Coons T, Lee J, Kupert E, Seminara D, Minna J, Bailey-Wilson JE, Wu X, Spitz MR, Eisen T, Houlston RS, Amos Cl, Anderson MW, You M. Familial aggregation of common sequence variants on 15q24-25.1 in lung cancer. J Natl Cancer Inst 2008; 100:1326-30.

103 Zhao D-ping, Yang C-lu, Zhou X, Ding J-an, Jiang G-ning, Zhao D, Jiang G. Association between CLPTM1L polymorphisms (rs402710 and rs401681) and lung cancer susceptibility: evidence from 27 case-control studies. Mol Genet Genomics 2014;289:1001-12.

104 Yang Y-C, Fu W-P, Zhang J, Zhong L, Cai S-X, Sun C. rs401681 and rs402710 confer lung cancer susceptibility by regulating TERT expression instead of CLPTM1L in East Asian populations. Carcinogenesis 2018;39:1216-21.

105 Marchesi M, Andersson E, Villabona L, Seliger B, Lundqvist A, Kiessling R, Masucci GV. HLA-dependent tumour development: a role for tumour associate macrophages? J Trans/ Med 2013;11:247

106 Evans DGR, Howell A. Breast cancer risk-assessment models. Breast Cancer Res 2007:9.

107 Mavaddat N, Michailidou K, Dennis J, Lush M, Fachal L, Lee A, Tyrer JP, Chen T-H, Wang Q, Bolla MK, Yang X, Adank MA, Ahearn T, Aittomäki K, Allen J, Andrulis IL, Anton-Culver H, Antonenkova NN, Arndt V, Aronson KJ, Auer PL, Auvinen P, Barrdahl M, Beane Freeman LE, Beckmann MW, Behrens S, Benitez J, Bermisheva
M, Bernstein L, Blomqvist C, Bogdanova NV, Bojesen SE, Bonanni B, Børresen-Dale A-L, Brauch H, Bremer M, Brenner H, Brentnall A, Brock IW, Brooks-Wilson A, Brucker SY, Brüning T, Burwinkel B, Campa D, Carter BD, Castelao JE, Chanock SJ, Chlebowski R, Christiansen H, Clarke CL, Collée JM, Cordina-Duverger E, Cornelissen S, Couch FJ, Cox A, Cross SS, Czene K, Daly MB, Devilee P, Dörk T, Dos-Santos-Silva I, Dumont M, Durcan L, Dwek M, Eccles DM, Ekici AB, Eliassen AH, Ellberg C, Engel C, Eriksson M, Evans DG, Fasching PA, Figueroa J, Fletcher O, Flyger $H$, Försti A, Fritschi L, Gabrielson M, Gago-Dominguez M, Gapstur SM, García-Sáenz JA, Gaudet MM, Georgoulias V, Giles GG, Gilyazova IR, Glendon G, Goldberg MS, Goldgar DE, González-Neira A, Grenaker Alnæs GI, Grip M, Gronwald J, Grundy A, Guénel P, Haeberle L, Hahnen E, Haiman CA, Håkansson N, Hamann U, Hankinson SE, Harkness EF, Hart SN, He W, Hein A, Heyworth J, Hillemanns P, Hollestelle A, Hooning MJ, Hoover RN, Hopper JL, Howell A, Huang G, Humphreys K, Hunter DJ, Jakimovska M, Jakubowska A, Janni W, John EM, Johnson $N$, Jones ME, Jukkola-Vuorinen $A$, Jung A, Kaaks R, Kaczmarek K, Kataja V, Keeman R, Kerin MJ, Khusnutdinova E, Kiiski Jl, Knight JA, Ko Y-D, Kosma V-M, Koutros S, Kristensen VN, Krüger U, Kühl T, Lambrechts D, Le Marchand L, Lee E, Lejbkowicz F, Lilyquist J, Lindblom A, Lindström S, Lissowska J, Lo W-Y, Loibl S, Long J, Lubiński J, Lux MP, Maclnnis RJ, Maishman T, Makalic E, Maleva Kostovska I, Mannermaa A, Manoukian S, Margolin S, Martens JWM, Martinez ME, Mavroudis D, McLean C, Meindl A, Menon U, Middha P, Miller N, Moreno F, Mulligan AM, Mulot C, Muñoz-Garzon VM, Neuhausen SL, Nevanlinna $H$, Neven P, Newman WG, Nielsen SF, Nordestgaard BG, Norman A, Offit K, Olson JE, Olsson H, Orr N, Pankratz VS, Park-Simon T-W, Perez JIA, Pérez-Barrios C, Peterlongo P, Peto J, Pinchev M, Plaseska-Karanfilska D, Polley EC, Prentice R, Presneau N, Prokofyeva D, Purrington K, Pylkäs K, Rack B, Radice P, Rau-Murthy R, Rennert G, Rennert HS, Rhenius V, Robson M, Romero A, Ruddy KJ, Ruebner M, Saloustros E, Sandler DP, Sawyer EJ, Schmidt DF, Schmutzler RK, Schneeweiss A, Schoemaker MJ, Schumacher F, Schürmann P, Schwentner L, Scott C, Scott RJ, Seynaeve C, Shah M, Sherman ME, Shrubsole MJ, Shu X-O, Slager S, Smeets A, Sohn C, Soucy P, Southey MC, Spinelli JJ, Stegmaier C, Stone J, Swerdlow AJ, Tamimi RM, Tapper WJ, Taylor JA, Terry MB, Thöne K, Tollenaar RAEM, Tomlinson I, Truong T, Tzardi M, Ulmer H-U, Untch $M$, Vachon CM, van Veen EM, Vijai J, Weinberg CR, Wendt C, Whittemore AS, Wildiers $H$, Willett W, Winqvist R, Wolk A, Yang XR, Yannoukakos D, Zhang Y, Zheng W, Ziogas A, Dunning AM, Thompson DJ, Chenevix-Trench G, Chang-Claude J, Schmidt MK, Hall P, Milne RL, Pharoah PDP, Antoniou AC, Chatterjee N, Kraft P, García-Closas M, Simard J, Easton DF, ABCTB Investigators, kConFab/AOCS Investigators, NBCS Collaborators. Polygenic risk scores for prediction of breast cancer and breast cancer subtypes. Am J Hum Genet 2019;104:21-34.

108 Pashayan N, Duffy SW, Neal DE, Hamdy FC, Donovan JL, Martin RM, Harrington P, Benlloch S, Amin Al Olama A, Shah M, Kote-Jarai Z, Easton DF, Eeles R, Pharoah $\mathrm{PD}$. Implications of polygenic risk-stratified screening for prostate cancer on overdiagnosis. Genet Med 2015;17:789-95.

109 Hsu L, Jeon J, Brenner H, Gruber SB, Schoen RE, Berndt SI, Chan AT, ChangClaude J, Du M, Gong J, Harrison TA, Hayes RB, Hoffmeister M, Hutter CM, Lin $Y$, Nishihara R, Ogino S, Prentice RL, Schumacher FR, Seminara D, Slattery ML, Thomas DC, Thornquist M, Newcomb PA, Potter JD, Zheng Y, White E, Peters U, Colorectal Transdisciplinary (CORECT) Study, Genetics and Epidemiology of Colorectal Cancer Consortium (GECCO). A model to determine colorectal cancer risk using common genetic susceptibility loci. Gastroenterology 2015;148:1330-9.

110 Natarajan P, Young R, Stitziel NO, Padmanabhan S, Baber U, Mehran R, Sartori S, Fuster V, Reilly DF, Butterworth A, Rader DJ, Ford I, Sattar N, Kathiresan S. Polygenic risk score identifies subgroup with higher burden of atherosclerosis and greater relative benefit from statin therapy in the primary prevention setting. Circulation 2017:135:2091-101.

111 Desikan RS, Fan CC, Wang Y, Schork AJ, Cabral HJ, Cupples LA, Thompson WK, Besser L, Kukull WA, Holland D, Chen C-H, Brewer JB, Karow DS, Kauppi K, Witoelar A, Karch CM, Bonham LW, Yokoyama JS, Rosen HJ, Miller BL, Dillon WP, Wilson DM, Hess CP, Pericak-Vance M, Haines JL, Farrer LA, Mayeux R, Hardy J, Goate AM, Hyman BT, Schellenberg GD, McEvoy LK, Andreassen OA, Dale AM. Genetic assessment of age-associated Alzheimer disease risk: development and validation of a polygenic hazard score. PLoS Med 2017;14:e1002258

112 Fahed AC, Wang M, Homburger JR, Patel AP, Bick AG, Neben CL, Lai C, Brockman D, Philippakis A, Ellinor PT, Cassa CA, Lebo M, Ng K, Lander ES, Zhou AY, Kathiresan S, Khera AV. Polygenic background modifies penetrance of monogenic variants for tier 1 genomic conditions. Nat Commun 2020;11:3635.

113 Lee Y-C, Lee Y-C, Li C-Y, Lee Y-L, Chen B-L. BRCA1 and BRCA2 Gene Mutations and Lung Cancer Risk: A Meta-Analysis. Medicina 2020;56:212.

114 Young RP, Hopkins RJ, Hay BA, Epton MJ, Mills GD, Black PN, Gardner HD, Sullivan $\mathrm{R}$, Gamble GD. A gene-based risk score for lung cancer susceptibility in smokers and ex-smokers. Postgrad Med J 2009;85:515-24.

$115 \mathrm{Kim}$ TJ, Kim HY, Goo JM, Sun JS. Risk prediction model for lung cancer screening. J Korean Soc Radiol 2019;80:860-71.

116 Spitz MR, Etzel CJ, Dong Q, Amos Cl, Wei Q, Wu X, Hong WK. An expanded risk prediction model for lung cancer. Cancer Prev Res 2008:1:250-4.

117 Raji OY, Agbaje OF, Duffy SW, Cassidy A, Field JK. Incorporation of a genetic factor into an epidemiologic model for prediction of individual risk of lung cancer: the Liverpool lung project. Cancer Prev Res 2010;3:664-9. 
118 Marcus MW, Raji OY, Duffy SW, Young RP, Hopkins RJ, Field JK. Incorporating epistasis interaction of genetic susceptibility single nucleotide polymorphisms in a lung cancer risk prediction model. Int I Oncol 2016;49:361-70.

119 Weissfeld JL, Lin Y, Lin H-M, Kurland BF, Wilson DO, Fuhrman CR, Pennathur A, Romkes M, Nukui T, Yuan J-M, Siegfried JM, Diergaarde B. Lung cancer risk prediction using common SNPs located in GWAS-identified susceptibility regions. J Thorac Oncol 2015;10:1538-45.

120 Qian DC, Han Y, Byun J, Shin HR, Hung RJ, McLaughlin JR, Landi MT, Seminara D, Amos Cl. A novel Pathway-Based approach improves lung cancer risk prediction using germline genetic variations. Cancer Epidemiol Biomarkers Prev 2016;25:1208-15.

121 Li H, Yang L, Zhao X, Wang J, Qian J, Chen H, Fan W, Liu H, Jin L, Wang W, Lu D. Prediction of lung cancer risk in a Chinese population using a multifactorial genetic model. BMC Med Genet 2012;13:118.

122 Field JK, Chen Y, Marcus MW, Mcronald FE, Raji OY, Duffy SW. The contribution of risk prediction models to early detection of lung cancer. J Surg Oncol 2013;108:304-11.

123 Dai J, Lv J, Zhu M, Wang Y, Qin N, Ma H, He Y-Q, Zhang R, Tan W, Fan J, Wang T, Zheng H, Sun Q, Wang L, Huang M, Ge Z, Yu C, Guo Y, Wang T-M, Wang J, Xu L, Wu W, Chen L, Bian Z, Walters R, Millwood IY, Li X-Z, Wang X, Hung RJ, Christiani DC, Chen H, Wang M, Wang C, Jiang Y, Chen K, Chen Z, Jin G, Wu T, Lin D, Hu Z, Amos $\mathrm{Cl}$, Wu C, Wei Q, Jia W-H, Li L, Shen H. Identification of risk loci and a polygenic risk score for lung cancer: a large-scale prospective cohort study in Chinese populations. Lancet Respir Med 2019;7:881-91.

124 Behravan H, Hartikainen JM, Tengström M, Pylkäs K, Winqvist R, Kosma V-M, Mannermaa A. Machine learning identifies interacting genetic variants contributing to breast cancer risk: a case study in Finnish cases and controls. Sci Rep 2018:8:1-13.

125 Martin AR, Kanai M, Kamatani Y, Okada Y, Neale BM, Daly MJ. Clinical use of current polygenic risk scores may exacerbate health disparities. Nat Genet 2019;51:584-91.

126 Lee A, Mavaddat N, Wilcox AN, Cunningham AP, Carver T, Hartley S, Babb de Villiers C, Izquierdo A, Simard J, Schmidt MK, Walter FM, Chatterjee N, Garcia-Closas M, Tischkowitz M, Pharoah P, Easton DF, Antoniou AC. Boadicea: a comprehensive breast cancer risk prediction model incorporating genetic and nongenetic risk factors. Genet Med 2019;21:1708-18.

127 Evans DGR, Harkness EF, Brentnall AR, van Veen EM, Astley SM, Byers H, Sampson S, Southworth J, Stavrinos P, Howell SJ, Maxwell AJ, Howell A, Newman WG, Cuzick J. Breast cancer pathology and stage are better predicted by risk stratification models that include mammographic density and common genetic variants. Breast Cancer Res Treat 2019;176:141-8.

128 Crosbie PA, Gabe R, Simmonds I, Kennedy M, Rogerson S, Ahmed N, Baldwin DR, Booton R, Cochrane A, Darby M, Franks K, Hinde S, Janes SM, Macleod U, Messenger M, Moller H, Murray RL, Neal RD, Quaife SL, Sculpher M, Tharmanathan P, Torgerson D, Callister ME. Yorkshire lung screening trial (YLST): protocol for a randomised controlled trial to evaluate invitation to community-based low-dose CT screening for lung cancer versus usual care in a targeted population at risk. BMJ Open 2020;10:e037075.

129 ClinicalTrials.gov. Manchester lung health study. Available: https://clinicaltrials.gov/ ct2/show/NCT04409444 [Accessed 8 Oct 2020].

130 Carozzi FM, Bisanzi S, Falini P, Sani C, Venturini G, Lopes Pegna A, Bianchi R, Ronchi C, Picozzi G, Mascalchi M, Carrozzi L, Baliva F, Pistelli F, Tavanti L, Falaschi F, Grazzini
M, Innocenti F, Paci E, Bartolucci M, Crisci E, Francisci A DE, Falchini M, Gabbrielli S, Roselli G, Aquilinini F, Cini S, De Santis M, Chella A, Comin C, Natali I, Battola L, De Liperi AL, Spinelli C, Maddau C, Fontanini G, Tognetti AR, Janni A, Masi A, Mussi A, Lucchi M, Vaggelli L, Vannucchi L, Petruzzelli A, Gadda D, Neri A, Niccolai F, Cordopatri G, Giusti F, Esposito I. Molecular profile in body fluids in subjects enrolled in a randomised trial for lung cancer screening: perspectives of integrated strategies for early diagnosis. Lung Cancer 2010;68:216-21.

131 Evans DG, Astley S, Stavrinos P, Harkness E, Donnelly LS, Dawe S, Jacob I, Harvie M, Cuzick J, Brentnall A, Wilson M, Harrison F, Payne K, Howell A. Project 2: assessment of predictive value of new genetic variants, 2016. Available: https://www.ncbi.nlm. nih.gov/books/NBK379496/ [Accessed 9 Oct 2020].

132 Abraham JE, Maranian MJ, Spiteri I, Russell R, Ingle S, Luccarini C, Earl HM, Pharoah PPD, Dunning AM, Caldas C. Saliva samples are a viable alternative to blood samples as a source of DNA for high throughput genotyping. BMC Med Genomics 2012;5.

133 Eeles RA, ni Raghallaigh H, The BARCODE1 Study Group. Barcode 1: a pilot study investigating the use of genetic profiling to identify men in the general population with the highest risk of prostate cancer to invite for targeted screening. JCO 2020;38:1505.

134 Leventhal K-G, Tuong W, Peshkin BN, Salehizadeh Y, Fishman MB, Eggly S, FitzGerald K, Schwartz MD, Graves KD. "Is it really worth it to get tested?": primary care patients' impressions of predictive SNP testing for colon cancer. J Genet Couns 2013;22:138-51.

135 Hall MJ, Ruth KJ, Chen DYT, Gross LM, Giri VN. Interest in genomic SNP testing for prostate cancer risk: a pilot survey. Hered Cancer Clin Pract 2015;13.

136 Young M-A, Forrest LE, Rasmussen V-M, James P, Mitchell G, Sawyer SD, Reeve K, Hallowell N. Making Sense of SNPs: Women's Understanding and Experiences of Receiving a Personalized Profile of Their Breast Cancer Risks. J Genet Couns 2018;27:702-8.

137 Nusbaum R, Leventhal K-G, Hooker GW, Peshkin BN, Butrick M, Salehizadeh Y, Tuong W, Eggly S, Mathew J, Goerlitz D, Shields PG, Schwartz MD, Graves KD. Translational genomic research: protocol development and initial outcomes following SNP testing for colon cancer risk. Trans/ Behav Med 2013;3:17-29.

138 Forrest LE, Sawyer SD, Hallowell N, James PA, Young M-A. High-risk women's risk perception after receiving personalized polygenic breast cancer risk information. J Community Genet 2019;10:197-206.

139 Cheung LC, Berg CD, Castle PE, Katki HA, Chaturvedi AK. Life-Gained-Based versus Risk-Based selection of smokers for lung cancer screening. Ann Intern Med 2019;171:623.

140 Callender T, Emberton M, Morris S, Eeles R, Kote-Jarai Z, Pharoah PDP, Pashayan $N$. Polygenic risk-tailored screening for prostate cancer: a benefit-harm and costeffectiveness modelling study. PLoS Med 2019;16:e1002998.

141 Naber SK, Kundu S, Kuntz KM, Dotson WD, Williams MS, Zauber AG, Calonge N, Zallen DT, Ganiats TG, Webber EM, Goddard KAB, Henrikson NB, van Ballegooijen M, Janssens ACJW, Lansdorp-Vogelaar I. Cost-Effectiveness of risk-stratified colorectal cancer screening based on polygenic risk: current status and future potential. JNCI Cancer Spectr 2020;4.

142 Duffy SW, Field JK. Mortality reduction with low-dose CT screening for lung cancer. N Engl J Med 2020;382:572-3.

143 Chiolero A, Paccaud F, Aujesky D, Santschi V, Rodondi N. How to prevent overdiagnosis. Swiss Med Wkly 2015;145. 